\title{
Can We Take the Religion out of Religious Decision-Making? The Case of Quaker Business Method
}

\author{
Rachel Muers $^{1}$ (D) $\cdot$ Nicholas Burton $^{2}$
}

Published online: 25 June 2018

(C) The Author(s) 2018

\begin{abstract}
In this paper, we explore the philosophical and theological issues that arise when a 'religious' process of decision-making, which is normally taken to require specific theological commitments both for its successful use and for its coherent explanation, is transferred into 'secular' contexts in which such theological commitments are not shared. Using the example of Quaker Business Method, we show how such a move provokes new theological questions, as well as questions for management studies.
\end{abstract}

Keywords Quakerism·Decision-making · Religious truth-claims

In this paper, we explore the philosophical and theological issues that arise when a 'religious' process of decision-making, which is normally taken to require specific theological commitments both for its successful use and for its coherent explanation, is transferred into 'secular' contexts in which such theological commitments are not shared. First, presenting our example (Quaker business method), we show how such a move provokes new theoretical - and theological questions, as well as questions for management and organisation studies. Second, we propose a response, grounded in a particular religious tradition but admitting of wider application, to one core question - namely that of the relationship between religious truth-claims and 'good' decisions.

\section{Quaker Business Method: Framing the Issues}

The Religious Society of Friends (Quakers) has a distinctive process for decisionmaking, developed over its 350-year history (Bradney and Cownie 2000; Mace 2012;

Rachel Muers

r.e.muers@leeds.ac.uk

Nicholas Burton

n.burton@northumbria.ac.uk

1 University of Leeds, Leeds, UK

2 Northumbria University, Newcastle upon Tyne, UK 
Sheeran 1983) - a process that has attracted interest in management and organisation studies as well as in theology, and that has from time to time been adopted and adapted for use in non-Quaker organisations (see Allen 2016; Burton 2017; Michaelis 2010). Notable features of the 'Quaker business method' include the lack of voting, of confrontational debate and of other practices that emphasise differences of opinion; an intentional shared search for unity, which is not understood as compromise or consensus; contemporaneous agreement of minutes (especially minutes of decision) in the meetings at which the decisions are taken, with the expectation of shared ownership of the decisions thereafter; and the use of reflective silence in meetings. Our focus in this paper, however, is not on the details of Quaker business method itself, but rather on the more general issues raised by its use beyond Quaker organisations. ${ }^{1}$

The first key point to note is that, in Quaker accounts of Quaker business method, it is explained in theological terms (see Anderson 2006; Grace 2000, 2006). According to standard Quaker accounts, a decision-making meeting is, like a Quaker meeting for worship, a process of collectively seeking to discern the will of God for the group in relation to the decision at hand. Thus, the British Quaker 'book of discipline' that serves as the authoritative account of Quaker faith and practice in Britain ${ }^{2}$ states concerning Quaker decision-making:

In our meetings for worship we seek through the stillness to know God's will for ourselves and for the gathered group. Our meetings for church affairs [sc. decisionmaking meetings] are also meetings for worship based on silence, and they carry the same expectation that God's guidance can be discerned if we are truly listening... (Britain Yearly Meeting 1994: 3.02).

The same passage goes on to use the 'belief that God's will can be recognised through the discipline of silent waiting' to distinguish Quaker decision-making from a 'secular idea' (consensus). Quakers often insist that the secular idea of consensus is based on negotiation between pre-established positions - requiring mutual compromise so that the decision taken is agreeable to all present, or at least objectionable to none (Anderson 2006). The Quaker process, by contrast, prioritises not compromise between different points of view but the collective search for a right way forward - understood as the will of God.

Quaker business method, then, both for authoritative collectively-agreed accounts and for a significant body of Quaker scholars, is not contingently but necessarily connected to specific theological beliefs held by Quakers. These beliefs - minimally, from the text above, that God exists, that God has a will, and that individuals and groups can perceive the will of God - explain, in the sense of justifying or providing a good enough reason for, specific features of the method (for example, in the quotation given above, the use of silence), and provide key connections in an account of how and why the whole method

\footnotetext{
${ }^{1}$ By 'Quaker organisations' we mean, for these purposes, organisations that explicitly claim Quaker identities and/or claim to shape their ways of working according to Quaker beliefs.

${ }^{2}$ The book of discipline, which is approved by the national Quaker body and periodically revised, includes both straightforwardly descriptive sections (for example, on the history of Quakerism) and straightforwardly normative sections (for example, on the requirements for the solemnisation of marriages). The sections discussed here, like much of the book, fall somewhere in between, as accounts of 'best practice' with an advisory character, explicitly open to revision in the light of experience. They are the nearest available approximation to an authoritative and normative account of Quaker business method.
} 
works. ${ }^{3}$ A corollary would seem to be that an explanation of Quaker business method either an account of why specific features are there, or an account of how the whole method makes sense - that omitted reference to these beliefs would fail, either in coherence or in accuracy. It would either be an incoherent explanation, or an incomplete explanation of Quaker business method.

The second key point to note is that - within this type of account of Quaker business method - beliefs are important not only at the level of explanation and justification, but at the level of practice. Consider, for example, the following description, synthesised from a range of sources, of how certain key features of Quaker business method relate to the search for divine guidance, or the attempt to discern the will of God (for relevant sources see Eccles 2009; Grace 2000, 2006; Mace 2012; Muers 2015).

Since the aim in Quaker decision-making is not to rely on the participants' views and opinions, but rather to learn the will of God for the group, the participants should not attempt to advocate for a specific point of view determined in advance, but rather to speak - and to listen - in ways that contribute to the shared search. The task of the 'chair' (the clerk) is to recognise and record the group's discernment - so he or she should offer suggested formulations of the decision and invite the group's further consideration, only moving on when it is clear that a right conclusion has been reached. Framing the meeting, and the various contributions, with reflective silence establishes the basic attitude of dependence on divine guidance, and enables prayerful attention to the matter at hand, to one another and to God.

It is apparent from this description, not only that Quaker business method as a practice is given theological explanations, but also that, if the explanations are correct, the method requires some specific set of beliefs and commitments on the part of those who participate. ${ }^{4}$ It looks as if - on Quaker terms - Quaker business method cannot be used by those who do not believe that God exists, that it is meaningful to talk about God having a will, or that individuals or groups can perceive the will of God. Indeed, given certain other characteristic Quaker beliefs and attitudes - most notably an emphasis on individual conviction, along with a suspicion of formal theology and of clerical or other religious hierarchy - it would be extremely surprising to find a theologically-framed method that was supposed to work, as it were, ex opere operato without the participants' beliefs and attitudes being relevant. ${ }^{5}$

To understand the particular weight that these theological explanations of Quaker business method carry, we need to remember that Quaker business method is not only 'distinctive', but

\footnotetext{
${ }^{3}$ Note that it is not claimed, in the texts we are citing, that Quaker business method as a whole or its specific features are necessary consequences of a belief in God (with the other linked beliefs), nor that these beliefs provide a full explanation or justification for the method. Some early Quaker controversial and apologetic literature did claim, both that Quaker worship was the only true form of worship and that all of its features were fully explained by the core beliefs. Contemporary accounts of Quaker worship have tended to leave much more space for contingency and plurality - and in any case we are not aware of any accounts of Quaker business method that make equivalent exclusive claims, despite the fact that Quaker business method is nearly as old as Quakerism.

${ }^{4}$ This is not to say that all participants have to have the same theological beliefs or commitments - but rather that some minimal core appears to be required.

${ }^{5}$ This is a somewhat risky extension of the expression ex opere operato - strictly referring, in sacramental theology, to the idea that sacraments derive their efficacy 'from the work worked' by Christ (as opposed to from any characteristics, activities or attitudes of those performing or receiving the sacraments). See for a lucid recent explanation Andrew Davison, Why Sacraments? (London: SCM, 2013), chapter 5.
} 
also - so it is widely claimed - unusual and (at least occasionally) surprising in the results it produces. Thus, for example, Robson's account of the decision by British Quakers in 2009 to approve the solemnisation of marriages for same-sex couples (before this was legal in the UK) highlights the rapid movement from controversy and uncertainty to clear approval, by a large national gathering, of a step more decisive and radical than any of the 'leaders' had expected (Robson 2013:169-188). On the standard Quaker description of the business method, which ties it closely to Quaker meetings for worship, its surprising effectiveness is connected to its reliance on divine guidance. While there are, to the best of our knowledge, no examples of Quaker business method (or to be precise, its success or surprising results) being used directly in apologetics - as an argument for the existence of God, or for the availability of divine guidance - there are texts in which it appears as a paradigmatic case of Quaker experience of God (Eccles 2009).

This being so, the question for those interested in the study of management and organisation (rather than narrowly in Quaker studies) is: what sense can be made of the successful use of processes taken from, and very closely linked to, Quaker business method in secular, or at least not-entirely-Quaker, contexts? That such successful uses do occur is increasingly widely attested (see for example Burton 2017; Lewis 2009; Michaelis 2010). Various parts of Quaker business method, including many that are listed in Quaker books of discipline and elsewhere in brief definitive accounts of the method, have been adopted outside Quaker structures. A considerable number of organisations that are 'Quaker-connected' but largely run by nonQuakers - and by people with no religious beliefs or affiliations - claim plausibly either to use Quaker business method or to shape their decision-making practices according to Quaker principles. For example, Michaelis (2010) documents the similarities of the decision-making processes to the Quaker business method in non-Quaker organisations as diverse as Churches Together, the Green Party, and Scottish Legal Aid Board. Furthermore, examples of for-profit organisations founded on religious principles continue to shape their decision-making processes according to processes consistent with the Quaker approach. The Scott Bader Commonwealth - a UK chemical manufacturing company established by a Quaker in 1921- retains references to "decision making... by unity rather than by a formal vote" in its constitution (Scott Bader 2010: 27). Since a Quaker business meeting itself - as opposed to the various things that might be written about it - involves more or less no explicitly theological language, and since, as indicated earlier, there are many 'components' of Quaker business method that, while unusual, can easily be learned and used independently, there are few obvious barriers to this transferability (see, for example, on 'transferring' the use of silence into non-Quaker organisations, Brigham and Kavanagh 2015; Lewis 2009; and for the development of an entire approach to corporate governance based on voteless participatory decision-making, Saxena and Jagota 2016).

Let us assume, for the purpose of argument, that at least some of these accounts of the successful transfer of Quaker business method to non-Quaker contexts are accurate. That is, let us assume that at least some people who do not hold the relevant beliefs have used the key practices and processes that comprise Quaker business method - including reflective silence, contemporaneous minute-taking, voteless decision-making, eschewal of partisan advocacy and have found that it works. How should we interpret the use of Quaker business method by non-Quakers - or more precisely, by people who do not share the beliefs taken by Quakers to be essential both to the adequate explanation and to the practice of Quaker business method?

One obvious response is to treat the 'transferability' of Quaker business method as evidence perhaps, conclusive evidence - that Quaker explanations of why and how their business 
method works are misguided. This could be argued in at least two ways. On the one hand, staying within broadly the same theological paradigm as the explanations themselves, the 'transferability' of Quaker business method into non-Quaker contexts might be taken to demonstrate that intention does not matter so much after all - that the will of God can be discerned through this method regardless of the attitudes of the participants (what I referred to above as ex opere operato). On the other hand, this 'transferability' might be taken to demonstrate that theological accounts of what is going on - at the level of explanation or justification - are either wrong or redundant. It is (we might say) not divine guidance - and the practice of collective seeking for divine guidance - that makes Quaker business method work; any explanations that rely on divine guidance are mistaken at best and mystifying at worst, and adequate explanations should rather be sought in the fields of (for example) psychology or organisational studies, employing a robust methodological agnosticism and focusing strictly on the commonalities between Quaker and non-Quaker organisations that employ the method.

An interesting feature of these two responses to the transferability of Quaker business method - two ways of using it as evidence against Quaker explanations of the method is that they are, to a certain extent, mirror-images of one another. The first preserves theological claims at the level of explanation (this really is a process that reveals the will of God) and discounts them at the level of practice (nobody needs to know or believe that for it to work). The second discounts theological claims at the level of explanation (the success of this process has nothing at all to do with God) but leaves open, at least theoretically, the possibility of their relevance in practice (it might perhaps work even better if some people believe they are seeking the will of God, even though they are mistaken). Neither looks as if it can be easily reconciled with the Quaker explanations of Quaker business method, discussed above; the second, indeed, looks prima facie as if it is incompatible with any religious commitment - although, as we shall see, the picture is somewhat more complicated. It looks as if Quakers committed to the standard Quaker view, presented with evidence that Quaker business method "works" beyond Quaker organisations and regardless of participant belief, will need either to deny the evidence or - perhaps more plausibly - to deny that what is being practised is Quaker business method at all, claiming that both its similarities to the latter and its success are, absent the theological foundations, mere coincidence.

We suggest, however, that this is not the only way to go. In the next section, we present and defend an alternative account of Quaker business method that can accommodate the 'transferability' of the processes into secular organisations, give a robust account of the method's strengths, and provide the best fit with Quaker theology and tradition. It is beyond the scope of this article to argue directly for the truth of this alternative account; our aim is merely to demonstrate that it might plausibly be accepted by people who are committed to certain core theological claims, while also making it possible fully to acknowledge, and indeed to enter into dialogue about, the successful use of a religious decision-making practice in secular contexts and by non-believers. In order to do so, we need to look more closely into the question of what it actually means to seek the will of God.

\section{Seeking the will of God: Truth in Quaker Business Method}

In what follows, we explore and critique two - superficially appealing, but theologically and practically deficient - models of what it means to seek the will of God, broadly fitting correspondence- and coherence-based accounts of religious truth. We then expound a third 
model that takes seriously the Quaker emphasis on the practical and experimental character of human appropriations of divine truth.

The first assumption that readers are likely to make, when they see a reference to 'seeking the will of God' in relation to a collective decision, is that the 'will of God' corresponds to some pre-determined 'right' decision'. On this view - which fits well with, although it does not

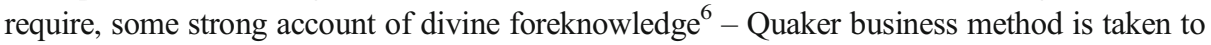
be a fairly reliable process for discovering a 'right' decision that exists out there before the process begins. The search for the right decision is analogous to the attempt to make truthful claims about God on a 'correspondence' theory of truth - there is a reality in God (in this case, the 'will of God' for a particular situation) to which a decision or a statement corresponds more or less adequately, and against which its rightness or truth is properly tested.

There are various problems with this account, both from a theological point of view and from the point of view of the empirical study of decision-making processes. Theologically, it tends to reinscribe an account of divine will and activity as inscrutable and arbitrary. Why, one might ask, would God hide God's will such that it can only or mainly be found through these idiosyncratic methods? From the point of view of the empirical study of decision-making, this view also tends to short-circuit any investigation of the specifics of Quaker business method particularly their similarities to processes and practices that have been developed independently of theological frameworks. Quaker decision-making, after all, is not altogether unlike consensus processes used in a wide range of organisations. Its attractiveness beyond Quaker organisations is linked to features that have recognisable analogues elsewhere - for example, the lack of hierarchy, the avoidance of group polarisation, the careful attention to the views and experiences of minorities, and indeed the commitment to taking as much time as is required to find the right decision.

It might, of course, be possible to qualify or add to the account in order to soften some of these objections. For example, the belief that the will of God is 'waiting to be discovered' is perfectly compatible with the belief that the will of God in any given situation is reflective of the character of God, as revealed and experienced within particular communities. The will of God, when we find it, will fit with what we already know, or what we have done before - even if it extends it in new and surprising ways. Moreover, when we start to give content to the character of God - as loving, as desiring reconciliation, healing and justice - it becomes even clearer that the will of God and the 'best decision', as at least in part perceivable from secular premises, are unlikely to be fundamentally opposed.

Nonetheless, the idea of seeking the will of God as 'trying to find the pre-existent right answer' retains its structural weaknesses as an account of Quaker business method. It frustrates attempts to make sense of why and how the process works - while also being liable to produce over-attachment to unimportant details of the process. If the process cannot be interpreted rationally, there is no basis on which to make judgements about which parts of it matter most, or how it might legitimately be altered.

As a secondary point, it is worth noting that this account of seeking the will of God also requires us to present the conclusion of a decision-making process primarily as a finding of fact, rather than as an action - 'we have discovered that $\mathrm{x}$ is the will of God', rather than 'we now do $\mathrm{x}$ '. Although it is not absolutely necessary for an account of decision-making to maintain the distinction between (in Aristotelian terms) the theoretical and the practical syllogism, it has been noted that the minutes of decision in Quaker business meetings are in

\footnotetext{
${ }^{6}$ It does not actually require God to know in advance what will be decided, only what should be decided.
} 
practice often framed as actions, that is, as present-tense collective illocutionary acts (we accept, we ask, we commit ourselves; see on this Muers 2015:194).

Looking at contemporary Quaker discussions of Quaker business method, however, it is not obvious that the 'guess the right answer' correspondence-theory account of the will of God is the only or the dominant option. There is a significant 'minority report' within which unity or agreement within the group, reached through a right process, just is the will of God. God does not actually have a 'will', Quakers might say, about what colour the carpet should be in the Quaker meeting house; there is no pre-existing right answer that everyone is trying to work out or guess. The will of God is, rather, that the process - which, as noted above, has manifest advantages for the individuals and the group - is used well, resulting in a decision that 'works' for the group. To continue the account developed above, the search for the right decision here is somewhat analogous to the attempt to make truthful claims about God on a 'coherence' theory of truth. Decisions are tested, not against their correspondence to some reality in God but against their fit with - in this case - the beliefs, needs and practices of the group, which as a coherent whole reflects the will of God. ${ }^{7}$

This approach seems to give a much better account of the transferability of Quaker business method into secular contexts. What it risks losing, however, is an important aspect of what participants in Quaker decision-making are actually doing. In at least some cases, they are not simply trying to find unity among the group; they are trying to discern the will of God on a specific issue. Moreover, as we have seen, this intention - to try to discern the will of God does materially affect how they behave; if they all started believing that there was no will of God apart from 'everybody coming to agreement and owning the decision', the process, at least on Quaker terms, would not work in the same way. Lest it be thought that the transferability of Quaker business method into non-Quaker contexts undercuts this objection, we could even restate it in non-religious terms. For at least some decision-making processes to work well, those involved have to be committed, not only to finding agreement within the group, but also to some wider contexts or criteria by which truth or success can be judged and to which the decision-makers are accountable. A good decision is - at least some of the time not simply a decision that everybody likes, or that works well for this group of people. In other words, while, as we have seen, Quaker literature uses the idea of 'seeking the will of God' to differentiate Quaker business method from a consensus process, it is also possible and indeed important to differentiate 'good decisions' from consensus. The gap between 'good decisions' and consensus can be seen in the (admittedly limited) literature on 'good decisions'. Often, a 'good' decision is defined from a utilitarian perspective, inclusive of a both benefit-cost analysis and risk analysis (see, Broadman et al. 2000; Dietz et al. 2001). Focusing on environmental decision-making, Dietz (2003) broadens the criteria for a 'good' decision as one that encompasses a range of factors, such as (i) human and environmental well-being, (ii) competence about facts and values, (iii) a fairness in process and outcome, (iv) one that relies upon human strengths, (v) a chance to for learning, and (vi) process efficiency (see also Renn et al. 1995).

Our preferred account of Quaker decision-making and its transferability holds together practical considerations - what process enables agreement to be reached, or a decision to be made? - with a robust commitment to the core idea of seeking truth, which differentiates the process from a search for consensus or compromise. Its further strength is that it takes as its starting point the distinctive

\footnotetext{
${ }^{7}$ To avoid any possible misunderstanding: this account of what it means to seek the will of God is perfectly compatible with the belief that God's reality is independent of statements about God. Coherence accounts of theological truth do not entail non-realism.
} 
historic Quaker understanding of truth - which is neither straightforwardly 'correspondence'-based nor straightforwardly 'coherence'-based. To simplify a complex story, Truth (capitalised) is used in Quaker writings to refer both to the God who is known and responded to, and to the way of life of the person who knows and responds to God (Britain Yearly Meeting 1994: 19:34 preamble); and the way of life that is Truth is characterised both by truthful speech and by right action (see the examples in Britain Yearly Meeting 1994:19.34-19.38).

The key claim for this paper is that in Quaker tradition, knowing truth, on the one hand, and living 'truthfully' or rightly, on the other, are inseparable and reciprocally related (Rediehs 2015; Muers 2015: 80ff). On the one hand, knowledge of the truth - we might say, correct belief - is not a simple prerequisite for right action; on the other hand, correct belief or knowledge is not an ultimate goal. Rather, knowledge of the truth and right action are mutually reinforcing and mutually generating. This approach has been described elsewhere, using Quaker terminology, as 'experimental' knowing - claims to knowledge are based on experience that arises from right action, and they serve in turn as the basis for further 'experiments' (Muers 2015:15). The truth about a person or a situation is how they are known when they are responded to rightly - and right response has both cognitive and enacted dimensions. Truths about God are also drawn into this reciprocal relation of knowledge and action; to follow divine guidance, or to do the will of God, is to engage with the world in certain ways that in turn generate new understanding of the will of God.

In Laura Rediehs' helpful account (2015), Gandhian 'nonviolence' serves as a valuable analogue for Quaker truth and demonstrates the close relationship between knowledge and action. To be nonviolent is both to perceive or know the other in a particular way (as valued, as inviolable) and to behave towards him or her in a particular way, and, crucially, the two moves are mutually required and mutually reinforcing, with a stance of active nonviolence leading to and enabling truthful perception. Likewise and very similarly, in Quaker tradition, 'answering that of God in everyone' entails both perceiving others in a particular way (as persons in and through whose lives God is revealed) and acting towards them accordingly. Nonviolence, in both Quaker and Gandhian tradition, means recognising and respecting things and persons as they are - but this recognition and respect (what we might call nonviolent knowledge) is only acquired through nonviolent relationships.

Similarly, the close relationship between knowledge and action extends, in the Quaker tradition, to management and organization. Quakers were instrumental in the development and creation of many industries in the eighteenth and nineteenth centuries, such as banking, chocolate, iron (Burton and Hope 2018). The UK Quakers \& Business group recently published a guide, "Good business: ethics at work", to emphasise a Quaker approach to business grounded in the discipline of respecting others and seeking T/truth, both discerned and enacted - whether employees, customers, suppliers, or communities within which the business operates (Quakers and Business 2014).

Within this framework, general or broad theological claims (such as the claim in business meetings we seek and find the will of God') are not primarily a description of a state of affairs. Rather, they are directions for both how to live truthfully and how to discern truth. Although they may imply claims about states of affairs (for example - God exists, God has a will that can be found), these claims cannot be evaluated independently of the practices that they generate. Formally, this approach to seeking and doing truth can look as if it results in circularity (assuming the truth-claim that supports the practice that is then used to justify the truth-claim). Substantively, however, since the claims are vague and the practice open-ended and exploratory - and indeed susceptible to failure - the circle is virtuous. In a process somewhat analogous to the testing of a 
scientific hypothesis (an analogy often referred to in discussions of early Quaker thought) a belief gives rise to an experimental practice that further refines or challenges the belief. ${ }^{8}$ A further important point about Quaker business method that is grasped more clearly in this account than in either of the foregoing is that the conclusion of a decision-making process is not a finding of fact, but an action - an action that is, nonetheless, inseparable from a process of 'seeking truth', and that is made intelligible by a specific understanding of the facts of the matter. 9

The other aspect of Rediehs' account of Quaker truth that is particularly relevant to the transferability of Quaker business method is that truth, in Quaker terms, is both divine and 'worldly'. There is not a special category of theological or religious truth. Knowing the truth about particular things in the world is only possible by acting towards them in accordance with the will of God - which entails respecting and recognising them as they are. The commitment to truth that begins with the accurate representation of ordinary facts is thus in direct continuity with the theologically-loaded commitment to capital-T Truth, the commitment that (for example) sustains well-known Quaker prophetic practices of 'speaking truth to power'.

Furthermore, it is a key principle of Quaker theological anthropology - and one that itself gives rise to specific 'experimental' practices of nonviolent relation to the other - that everyone has access to divine truth, regardless of their institutional or theological affiliations (Muers 2015). Everyone is in principle able, therefore, to orient herself towards the world, in terms of both action and perception, so that she sees it in the right way. This being so, Quakers should expect to see overlaps, continuities and close analogies between their decision-making processes and those of others - just as they should (and, from their writings, do) expect to see examples of right action and true judgement emerging in the lives of individuals.

The claim that everyone has access to divine truth does, it should be noted, raise significant questions at the intersections of Quaker practice and management practice - for example, in relation to the place and use of expertise. In the sphere of theology and worship - so, in relation to the knowledge of God and the practice of seeking God's will - Quakers have traditionally eschewed or de-centred 'expertise' (for example, by not appointing clergy). In decisionmaking processes on various complex issues, room has to be found for various kinds of expertise, and the tension between acknowledging distinctive expertise and prioritising the shared search for truth in which all can and should participate is an area of ongoing research in Quaker business method (Burton et al. Forthcoming). In the conversation with management studies more generally, however, the Quaker approach clearly calls into question the emphasis, in more positivist approaches to management, on the distinctive or unique value of the 'scientific' manager's technical expertise. Quaker business method, and its associated beliefs and practices, force us to pay attention to the 'expertise' of everyone - to the full range of experiences, value-laden perceptions, activities and contexts through which an organisation can learn and enact truth.

This last observation should also make it clear that the truth - or even the Truth - being discussed here is not perceived or known as if 'from nowhere'. Indeed, the claim to have a

\footnotetext{
${ }^{8}$ Quakers claim that their continued adherence to certain practices - including business method, but also silent unprogrammed worship - results from the continued or repeated experience that these practices work, to yield both better understanding of, and right response to, specific situations. For another articulation of the experiential/ experimental basis of Quaker practice, see Scott 1980. For the links between Quakerism and science, see for example Cantor 2005.

${ }^{9}$ This latter point is not, of course, distinctive to Quaker thought; it could usefully be developed further in dialogue, for example, with Aquinas' distinction between speculative and practical reason, on which see Osborne Jr 2012.
} 
'view from nowhere' would itself be significantly, and perhaps disastrously, untruthful - liable to result once again in a failure to respond rightly to the other as a knower and doer of truth. Again to cut short what would need to be a far longer discussion, the Quaker account of truth we propose is clearly realist, but in a way that recognises the situated, perspectival and partial character of all knowledge of the truth. ${ }^{10}$

\section{Summary and Conclusions}

We have argued that Quaker decision-making can be interpreted in a way that allows 'secular' appropriations of the process to be recognised and evaluated, by Quakers, on a continuum with Quaker uses of the process. They can be evaluated as experiments in living truthfully, in order to discern truth and act in accordance with the truth. Handling Quaker business method in this way neither requires 'secular' practitioners to accept theological claims, nor necessitates a reductionist reading of theology. The focus on truth discerned and truth enacted opens up a space in which God-talk can interact with management-talk without impugning the integrity of either discourse. Indeed, looking to the focus of this special issue, our paper shows that to bring together "God and Management" in a philosophical context is to open up the question of how the pursuit of truth arguably central to the philosophical endeavour as well as to many conceptions of the religious life - relates to the everyday pursuit of "good decisions" in management contexts.

Thus, while our account is specific to Quakers, and relies on a distinctive Quaker understanding of the relationship between truth and practice, it does suggest at the formal level that evaluations of the relationship between religious practices and their secular appropriations in management might benefit from detailed scrutiny of the core underlying assumptions - for example, about the nature of truth or about the criteria for 'good decisions'. Such scrutiny can also enable us better to perceive the key challenges posed by Quaker (and other religiously-based) decision-making processes to secular management contexts: how are decision-making processes enabling or inhibiting attention to the truth of a situation, and what are the criteria for success?

Any conversation about truth in management contexts would need at some point to answer questions about the location and operation of power within organisations. We suggest that this does not need to derail the conversation. Indeed, a fruitful area for further research would be the relationship between (expressed and enacted) understandings of divine power within religiouslybased decision-making processes, on the one hand, and theories of power in organisational decisionmaking, on the other. Once again the link with nonviolence, and particularly with Gandhian nonviolence (as suggested by Rediehs), would be worth exploring. In a management world in which metaphors of warfare tend to dominate, it is easy to forget, or to fail to draw on, the considerable body of thought that understands nonviolence as a mode of power - albeit one that is inseparable from ethical commitments and from the pursuit of truth. A fuller discussion of this dimension of the relationship of "God and Management", however, must await future research.

Open Access This article is distributed under the terms of the Creative Commons Attribution 4.0 International License (http://creativecommons.org/licenses/by/4.0/), which permits unrestricted use, distribution, and reproduction in any medium, provided you give appropriate credit to the original author(s) and the source, provide a link to the Creative Commons license, and indicate if changes were made.

${ }^{10}$ For more on all these issues see the collection of essays in Dudiak 2015; see in particular Beals 2015 on Quaker responses to postmodernity. 


\section{References}

Allen, Stephen. 2016. Learning from friends: Developing appreciations for unknowing in reflective practice. Management Learning 48 (2): 125-139.

Anderson, Paul. 2006. The Meeting for Worship in which Business is Conducted: Quaker Decision-Making as a Factor of Spiritual Discernment. Quaker Religious Thought 106/4.

Beals, Corwynn. 2015. Tasting truth: The condition of our postmodern condition, a(nother) report on knowledge. In Befriending Truth: Quaker Perspectives, ed. Jeffrey Dudiak, 122-135. Philadelphia, PA: Friends Association for Higher Education.

Bradney, Anthony, and Fiona Cownie. 2000. Living without law: an ethnography of Quaker decision-making, dispute avoidance and dispute resolution. Aldershot, UK: Ashgate.

Brigham, Martin \& Kavanagh, Donncha. 2015. The sense of the meeting: silent organisation. Paper presented at European Group of Organizational Studies (EGOS) Annual Conference Athens, Greece. July 2015.

Britain Yearly Meeting. 1994. Quaker faith and practice: The book of Christian discipline of the yearly meeting of the Religious Society of Friends (Quakers) in Britain. London: Britain Yearly Meeting.

Broadman, Anthony, David Greenberg, Aiden Vining, and David Weimer. 2000. Cost-benefit analysis: Concepts and Practices. Upper Saddle River, NJ: Pearson Education.

Burton, Nicholas. 2017. Quaker Business Method: A Contemporary Decision-making Process. In Quakers, business and industry, ed. S. Angell and P. Dandelion. United States: Friends Association for Higher Education.

Burton, Nicholas, and Alex Hope. 2018. Responsibility in business: what can we learn from the Quakers? In Quakers, Politics and Economics, ed. D. Ross and M. Snarr. PA, USA: Friends Association of Higher Education.

Burton, Nicholas, Juliette Koning and Rachel Muers. Forthcoming. Organisational ethnography and religious organisations: The case of Quaker decision-making practice. Journal of Management, Spirituality and Religion.

Cantor, Geoffrey. 2005. Quakers, Jews and science: religious responses to modernity and the sciences, 16501900. Oxford: Oxford University Press.

Dietz, Thomas. 2003. What is a good decision? Criteria for Environmental Decision Making. Human Ecology Review 10 (1): 33-39.

Dietz, Thomas, Scott Frey, and Eugene Rosa. 2001. Risk assessment and management. In The environment and society reader, ed. R.S. Frey, 272-299. New York: Allyn and Bacon.

Dudiak, Jeffrey, ed. 2015. Befriending Truth: Quaker Perspectives. Philadelphia: Friends Association for Higher Education.

Eccles, Peter. 2009. The presence in the midst. London: Quaker Books.

Grace, Eden. 2000. An introduction to Quaker business practice, paper presented at the subcommittee meeting of the Special Commission on Orthodox Participation in the World Council of Churches Damascus, Syria. March 2000.

Grace, Eden. 2006. Voting not to vote: toward consensus in the WCC, Quaker Religious Thought 106/4.

Lewis, Martin. 2009. 'Doing Business the Quaker Way'. Forbes. http://www.forbes.com/2009/10/09/quakerbusiness-meetings-leadership-society-friends.html (accessed 17th July 2017).

Mace, Jane. 2012. God and Decision-Making. London: Quaker Books.

Michaelis, Laurie. 2010. Transforming impasse: The way through conflict with Quaker listening Processes. Paper produced by the Quaker Council for European Affairs (QCEA).

Muers, Rachel. 2015. Testimony: Quakerism and Theological Ethics. London: SCM Press.

Osborne, Thomas, Jr. 2012. Practical reasoning. In The Oxford handbook of Aquinas, ed. Brian Davis. Oxford: Oxford University Press.

Quakers and business. 2014. Good business: ethics at work. 2nd ed. London: Quakers and business group.

Rediehs, Laura. 2015. Truth and nonviolence: Living experimentally in relation to truth. In Befriending truth: Quaker perspectives, ed. Jeffrey Dudiak. Philadelphia, PA: Friends Association for Higher Education.

Renn, Ortwin, Thomas Webler, and Peter Wiedemann. 1995. Fairness and competence in citizen participation: Evaluating models for environmental discourse. Dordrecht: Kluwer Academic Publishers.

Robson, Susan. 2013. Living with Conflict: A Challenge to a Peace Church. London: Scarecrow Press.

Saxena, Anand, and Rajni Jagota. 2016. Could Sociocracy be the way to MSME governance? Indian Journal of Corporate Governance 9 (2): 173-185.

Scott, Janet. 1980. What Canst Thou Say? Towards a Quaker Theology. London: Quaker Books.

Scott Bader Commonwealth Limited. 2010. Constitution. Available from http://www.scottbader. com/uploads/files/4258_comms-book-11nov.pdf (accessed 17th July 2017).

Sheeran, Michael. 1983. Beyond majority rule. Philadelphia yearly meeting of the religious Society of Friends, Pennsylvania. 
Rachel Muers is Senior Lecturer in Christian Studies at the University of Leeds, UK. She is the author of several books, including Testimony: Quakerism and Theological Ethics (SCM 2015).

Nicholas Burton is Senior Lecturer at Newcastle Business School, Northumbria University, UK. His main research interests include spirituality in management and law. 